\title{
Survival of Freeze-dried Leuconostoc mesenteroides and Lactobacillus plantarum Related to Their Cellular Fatty Acids Composition during Storage
}

\author{
Ibourahema Coulibaly • Anastasie Yao Amenan • \\ Georges Lognay • Marie Laure Fauconnier • \\ Philippe Thonart
}

Received: 29 January 2008 / Accepted: 31 March 2008 /

Published online: 20 May 2008

(C) Humana Press 2008

\begin{abstract}
Lactic acid bacteria strains Lactobacillus plantarum CWBI-B534 and Leuconostoc ssp. mesenterö̈des (L. mesenterö̈des) Kenya MRog2 were produced in bioreactor, concentrated, with or without cryoprotectants. In general, viable population did not change significantly after freeze-drying $(p>0.05)$. In most cases, viable population for cells added with cryoprotectants was significantly lower than those without $(p<0.05)$. Cellular fatty acids (CFAs) from the two strains in this study were analyzed before and after freeze-drying. Six CFAs were identified, namely, palmitic $\left(\mathrm{C}_{16: 0}\right)$, palmitoleic $\left(\mathrm{C}_{16: 1}\right)$, stearic $\left(\mathrm{C}_{18: 0}\right)$, oleic $\left(\mathrm{C}_{18: 1}\right)$, linoleic $\left(\mathrm{C}_{18: 2}\right)$, and linolenic $\left(\mathrm{C}_{18: 3}\right)$ acids were identified. Four of them, $\mathrm{C}_{16: 0}, \mathrm{C}_{16: 1}$, $\mathrm{C}_{18: 0}$, and $\mathrm{C}_{18: 1}$, make up more than $94 \%$ or $93 \%$ of the fatty acids in L. mesenteroides and L. plantarum, respectively, with another one, namely, C18:3, making a smaller (on average $5-6 \%$, respectively) contribution. The $\mathrm{C}_{18: 2}$ contributed very small percentages (on average $\leq$ $1 \%$ ) to the total in each strain. $\mathrm{C}_{16: 0}$ had the highest proportion at most points relative to other fatty acids. Moisture content and water activity $\left(a_{\mathrm{w}}\right)$ increased significantly during the storage period. It was observed that $\mathrm{C}_{16: 1} / \mathrm{C}_{16: 0}, \mathrm{C}_{18: 0} / \mathrm{C}_{16: 0}$ and $\mathrm{C}_{18: 1} / \mathrm{C}_{16: 0}$ ratios for freeze-dried
\end{abstract}

Coulibaly Ibourahema and Yao Amenan Anastasie equally contributed to this work.

I. Coulibaly $(\bowtie) \cdot$ P. Thonart

Unité des Bio-industries, Centre Wallon de Biologie Industrielle (CWBI), Faculté Universitaire des Sciences Agronomiques de Gembloux (FUSAGx), Passage des Déportés 2, B-5030 Gembloux, Belgium e-mail: bioindus@fsagx.ac.be

A. Y. Amenan $(\bowtie) \cdot$ P. Thonart

Service de Technologie Microbienne, Centre Wallon de Biologie Industrielle (CWBI),

Université de Liège (ULg), Sart Tilman, B40 B-4000 Liège, Belgium

e-mail: bioindus@fsagx.ac.be

M. L. Fauconnier

Unité de Biologie végétale (BV), Faculté Universitaire des Sciences Agronomiques de Gembloux (FUSAGx), Passage des Déportés 2, B-5030 Gembloux, Belgium

G. Lognay

Unité de Chimie Analytique (CA), Faculté Universitaire des Sciences Agronomiques de Gembloux (FUSAGx), Passage des Déportés 2, B-5030 Gembloux, Belgium 
L. mesenteroides or L. plantarum, with or without cryoprotectants, did not change significantly during the storage period. According to the packaging mode and storage temperatures, $\mathrm{C}_{18: 2} / \mathrm{C}_{16: 0}$ and $\mathrm{C}_{18: 3} / \mathrm{C}_{16: 0}$ ratios for freeze-dried $L$. mesenteroides and L. plantarum with or without cryoprotectants decreased as the storage time increased. However, a higher $\mathrm{C}_{18: 2} / \mathrm{C}_{16: 0}$ or $\mathrm{C}_{18: 3} / \mathrm{C}_{16: 0}$ ratio for L. mesenteroides and L. plantarum was noted in the freeze-dried powder held at $4{ }^{\circ} \mathrm{C}$ or under vacuum and in dark than at $20{ }^{\circ} \mathrm{C}$ or in the presence of oxygen and light.

Keywords Viability $\cdot$ Oxidative stress $\cdot$ Heat stress $\cdot$ Freeze-drying $\cdot$ Cellular fatty acids $\cdot$ Lactic acid bacteria

$\begin{array}{ll}\text { Abbreviations } \\ a_{\mathrm{w}} & \text { water activity } \\ \mathrm{CFA} & \text { cellular fatty acid } \\ K & \text { Inactivation rate } \\ k_{a} & \text { acidification loss rate } \\ L & \text { Leuconostoc } \\ \mathrm{LAB} & \text { Lactic acid bacteria } \\ \text { Lb } & \text { Lactobacillus } \\ \mathrm{Me} & \text { Methyl esterified } \\ \mathrm{MUFA} & \text { Monounsaturated fatty acids } \\ \mathrm{P} & \text { cell without cryoprotectants } \\ \text { PC } & \text { cell with cryoprotectants } \\ \mathrm{PUFAs} & \text { Polyunsaturated fatty acids } \\ R^{2} & \text { Determination coefficient } \\ \mathrm{RH} & \text { Relative humidity } \\ \mathrm{S} & \text { saturated fatty acids } \\ \mathrm{Tg} & \text { Temperature of glass transition } \\ \mathrm{Ts} & \text { Surface temperature of product } \\ \mathrm{U} & \text { Unsaturated fatty acids }\end{array}$

\section{Introduction}

The introduction of appropriate starter culture techniques may constitute one major step toward improved safety, quality, and security of traditional small-scale fermentation in Africa [1]. The industrial use of lactic starter cultures for the food industry depends on the concentration and preservation technologies employed, which are required to warrant longterm delivery of stable cultures in term of viability and functional activity [2]. Freezedrying has commonly been used for this purpose; nevertheless freeze-dried cells are likely to lose their viability during storage [3-5]. Lipid oxidation of membrane fatty acids was deemed responsible for cell death during storage [6]. This is supported by indirect evidence presented in previous reports. For example, chemical injury in the form of free radical damage has been suggested by most researchers as one of the major culprits in desiccation injury [7]. Loss of water increases the ionic concentration (which can lead to the formation of reactive oxygen species [ROS]), and in the dry state, bio-molecules become more susceptible to the attack of oxygen. These species can damage proteins, modify bases and sugars in deoxyribonucleic acid (DNA) and cause lipid peroxidation [7, 8]. It is reported 
that the presence of antioxidants increased the survival rate of dried bacteria during storage $[6,9]$. There is a strong similarity between the loss of viability and the increase in freeradical concentration during storage of freeze-dried Serratia marcescens [10]. This hypothesis is supported by others authors, who found that the reactions between carbonyl compounds and cellular components are a major cause of mortality during storage of dried microorganisms [11]. However, to date no papers have been published identifying which bacterial cellular fatty acids are in fact oxidized or degraded during storage. In living organisms lipids, particularly polyunsaturated fatty acid (PUFA) components of cell membranes, are described as being extremely subject to environmental stress [12, 13]. Stresses such as decreases in $a_{w}$ [14] or increases in temperature [15] are known to affect the fatty acid composition of bacteria. A number of factors, such as temperature, atmosphere, exposure to light and moisture influence the viability of freeze-dried cultures [16]. It is well established that cryoprotectants are almost indispensable when freezing and drying microorganisms, but the contribution of these compounds to stability of dried microorganisms during storage is discussed [17]. The disadvantages of dried cultures undermine their application, but advantages can outweigh disadvantages if the inactivation during storage can be more clearly understood and consequently reduced. Therefore, the purpose of this work was to study the influence of oxygen, humidity, and temperature on survival or cellular fatty acids of freeze-dried L. mesenteroides and L. plantarum, with or without cryoprotectants, during storage and, if possible, to show the interrelation between viability and polyunsaturated fatty acids degradation. We used whole-cell fatty acid methyl ester (FAME) analysis to examine the effect of storage conditions on fatty acid composition, as this approach reflects the fatty acid composition of phospholipids and lipopolysaccharides [18-20].

\section{Materials and Methods}

\section{Microorganisms and Cultivation}

The lactic acid bacteria L. mesenteroides ssp. mesenteroides Kenya MRog2, isolated and identified from cassava fermentation for gari production [21], was provided by the Federal Research Centre for Nutrition, Institute of Hygiene and Toxicology (Karlsruhe, Germany). The L. plantarum CWBI-B534 was isolated from poultry farms in the vicinity of Dakar (Senegal, West Africa). MRS broths inoculated with each strain were incubated at $30{ }^{\circ} \mathrm{C}$ for $18 \mathrm{~h}$. The supernatants obtained after centrifugation (Sorvall RC2-B, Sorvall, USA) at $2,500 \times \mathrm{g}$ for $20 \mathrm{~min}$, were decanted. The cell pellets obtained were resuspended in $5 \mathrm{ml}$ $(50 \% v / v)$ glycerol and frozen at $-80{ }^{\circ} \mathrm{C}$.

\section{Productions}

The strains were grown in $500 \mathrm{~L}$ bioreactor containing MRS medium for $18 \mathrm{~h}$ and then concentrated 20 times by centrifugation. After centrifugation, cryoprotectants $(2 \%(w / w)$ glycerol and 5\% (w/w) maltodextrine)) were added to the pellets (PC). Cell suspensions without additives were used as control $(\mathrm{P})$. Cells were freeze-dried in a low freeze-drier (Leybold, Belgium) with a standard program by increasing the temperature gradually from $-45{ }^{\circ} \mathrm{C}$ to $25{ }^{\circ} \mathrm{C}$ at 0.9 mbar pressure $(30 \mathrm{~h})$ followed by $15 \mathrm{~h}$ at 0.15 mbar. All fermentations were done in duplicate and average values reported. 
Storage Conditions

Freeze-dried samples were stored during 90 days, in portion size $(2 \pm 0.5 \mathrm{~g}$ in each portion) at $20{ }^{\circ} \mathrm{C}$ (accelerated stability test, $30 \% \mathrm{RH}$ ) and at $4{ }^{\circ} \mathrm{C}$ (stability at refrigerated temperature, $70 \% \mathrm{RH}$ ). At each storage temperature, samples were stored, in open 20-ml white glass tubes and in aluminum foil packets which were vacuum-sealed. Samples were withdrawn for analysis each 30 days and kept at $-20{ }^{\circ} \mathrm{C}(48-72 \mathrm{~h})$ before analysis.

\section{Dry Cell Weight and Water Content Determinations}

The dry cell weight of $1 \mathrm{~g}$ of powder was determined at the end of freeze drying. The water content (100 g dry weight $)^{-1}$ of the freeze-dried samples during storage at 20 and $4{ }^{\circ} \mathrm{C}$ with aeration was determined each 15 days. The samples were dried in a convection oven until constant weight and results are mean of four determinations.

\section{Water Activity Measurements}

The water activity $\left(a_{\mathrm{w}}\right)$ of the freeze-dried samples was measured at $25{ }^{\circ} \mathrm{C}$ using a water activity meter Novasina (Novasina, Pfäffikon, Switzerland). Standard salt solutions (Novasina) of known water activity were used for calibration of the sensor at the measuring temperature. Readings were taken until four sequential readings gave the same results. Results obtained were the average of four determinations for each sample.

Survival Rate

Percentage survival of the strains after freeze-drying process was expressed as follows:

$$
\operatorname{Survival}(\%)=\frac{C_{2} \times P_{2}}{C_{1} \times P_{1}} \times 100
$$

where $C_{1}$ and $C_{2}$ are the $\mathrm{CFU} / \mathrm{g}$ of the suspension before and after freeze-drying and $P_{1}$ and $P_{2}$ are amount of matter obtained before and after freeze-drying. Percentage survival after a 90-day storage was calculated as $100 \times N / N_{0}$, where $\mathrm{N}$ is the $\mathrm{CFU} / \mathrm{g}$ of the freeze-dried sample at a given time and $\mathrm{N}_{0}$ is the $\mathrm{CFU} / \mathrm{g}$ of the sample at the end of freeze-drying.

\section{Analysis of Cellular Fatty Acids}

Cells wall fractions were obtained as described previously [22]. The lipids were extracted overnight from cell wall fractions $(2.5 \mathrm{ml})$ and dried cells $(1 \mathrm{~g})$ with ethanol-ether $(3: 1 \mathrm{v} / \mathrm{v})$ mixture according to an adaptation of the method of Ito (1969). Ethanol ether extracts were pooled, filtered, and then evaporated and concentrated under reduced pressure at $35{ }^{\circ} \mathrm{C}$. Fatty acid methyl esters (FAME) were prepared from the concentrate with $14 \%(w / w)$ solution of boron trifluoride in methanol as reagent (Sigma, St Louis, MO, USA). After heating at $70{ }^{\circ} \mathrm{C}$ in a water bath for $90 \mathrm{~min}, 0.5 \mathrm{ml}$ of saturated $\mathrm{NaCl}, 0.2 \mathrm{ml}$ of sulfuric acid $(10 \%)$ and $0.5 \mathrm{ml}$ of $n$-hexane were added. The methylated fatty acids were extracted from the upper phase after decanting by means of a Pasteur pipette. Gas chromatographic analysis of the methyl esters was carried out on a HP 6890 (Hewlett Packard) gas chromatograph equipped with a flame ionization detector at $250{ }^{\circ} \mathrm{C}$. A capillary column 
$(30 \times 0.25 \mathrm{~mm}$ (i.d), film thickness $0.25 \mu \mathrm{m})$ was used. Helium was used as carrier gas $(2.4 \mathrm{ml} / \mathrm{min})$ and the injection volume was $1 \mu \mathrm{l}$. Injection was done at $250{ }^{\circ} \mathrm{C}$ in splitless mode for $1 \mathrm{~min}$. The oven temperature was held at $50{ }^{\circ} \mathrm{C}$ for $1 \mathrm{~min}$, increased by $30{ }^{\circ} \mathrm{C} / \mathrm{min}$ to $150{ }^{\circ} \mathrm{C}$, and then from $150{ }^{\circ} \mathrm{C}$ to $240{ }^{\circ} \mathrm{C}$ at $4{ }^{\circ} \mathrm{C} / \mathrm{min}$ with a final hold of $10 \mathrm{~min}$ at $240{ }^{\circ} \mathrm{C}$. Fatty acids methyl esters were identified by comparing their retention times with standard mixtures FAME MIX 47885U (Supelco, Bellefonte, USA). The relative fatty acid content was estimated as a percentage of the total peak area using a DP 700 integrator (Spectra physics). The relative content (\%) of each fatty acid was normalized by expressing it as a ratio of the relative content (\%) of palmitic (C16:0) acid for two reasons: [1] C16:0 had the highest proportion at most points relative to other fatty acids, [2] C16:0 did not change significantly during storage $(p>0.05)$

Statistical Analysis

Productions in bioreactor were done in duplicate. The mean values and the standard deviation were obtained with four determinations. These data were then compared by Turkey's honestly significant difference (Statistica 7.1, StatSoft Inc. 2005). The level of significance was determined at $p<0.05$. (CFU counts were transformed to their base 10 logarithms.)

\section{Results and Discussion}

\section{Survival of Lactic Acid Bacteria after Freeze-drying}

Lactic acid bacteria L. mesenteroides and L. plantarum were produced in bioreactor; the cells were harvested, added or not with cryoprotectants (5\% maltodextrine, $2 \%$ glycerol) and freeze-dried. Table 1 shows viable counts during the process and survival after freezedrying. A viable population of $11.93 \pm 0.02 \log _{10} \mathrm{CFU} / \mathrm{g}$ or $11.65 \pm 0.04 \log _{10} \mathrm{CFU} / \mathrm{g}$ and $11.88 \pm 0.03 \log _{10} \mathrm{CFU} / \mathrm{g} g$ or $11.65 \pm 0.04 \log _{10} \mathrm{CFU} / \mathrm{g}$ for L. mesenteroides and L. plantarum, added or not with cryoprotectants, were obtained after the freeze-drying process. Different survival rates were obtained immediately after freeze-drying. $L$. plantarum successfully survived or recovered more than $90 \%$ of population values, whereas $L$. mesenteroides behaved with low biomass yield $(<11 \%)$. The effect of the additives is not significant. Moisture content and $a_{\mathrm{w}}$ were determined every 15 days during

Table 1 Viability of L. mesenteroides and L. plantarum before and after freeze-drying.

\begin{tabular}{|c|c|c|c|}
\hline Population $(\log \mathrm{CFU} / \mathrm{g})$ & Treatment $^{\mathrm{a}}$ & L. mesenteroides & L. plantarum \\
\hline \multirow[t]{2}{*}{ Before freeze-drying } & $\mathrm{P}$ & $11.8 \pm 0.03 \mathrm{a}^{1}$ & $11.8 \pm 0.05 \mathrm{ab}$ \\
\hline & $\mathrm{PC}$ & $11.7 \pm 0.08 \mathrm{~b}$ & $11.7 \pm 0.05 \mathrm{a}$ \\
\hline \multirow[t]{2}{*}{ After freeze-drying } & $\mathrm{P}$ & $11.9 \pm 0.02 \mathrm{a}$ & $11.9 \pm 0.03 \mathrm{~b}$ \\
\hline & $\mathrm{PC}$ & $11.6 \pm 0.04 \mathrm{~b}$ & $11.6 \pm 0.04 \mathrm{a}$ \\
\hline \multirow[t]{2}{*}{ Survival $(\%)^{b}$} & $\mathrm{P}$ & $13 \pm 2$ & $94 \pm 4$ \\
\hline & $\mathrm{PC}$ & $18 \pm 1$ & $97 \pm 5$ \\
\hline
\end{tabular}

Values are means \pm standard deviation $(\mathrm{SD})(n=4)$

${ }^{\text {a }} \mathrm{P}$, cells without cryoprotectants; PC, cells with cryoprotectants ( $5 \%$ maltodextrine, $2 \%$ glycerol)

${ }^{\mathrm{b}}$ Values represent percentage survival of the strain after freeze-drying process

${ }^{1}$ Cell count values in the same column with different letters are significantly different $(p<0.05)$ 
storage at $4{ }^{\circ} \mathrm{C}(70 \% \mathrm{RH})$ and $20{ }^{\circ} \mathrm{C}(30 \% \mathrm{RH})$ in open white glass tube containing $2 \pm$ $0.2 \mathrm{~g}$ of dried powder. The relationship between $a_{\mathrm{w}}$ and moisture content $(100 \mathrm{~g}$ dry weight $)^{-1}$ for freeze-dried strains during storage at 4 or $20^{\circ} \mathrm{C}$ was established for storage in open white glass tube. The water contents were stable in vacuum-sealed aluminum foil at the same temperature. Moisture content and $a_{\mathrm{w}}$ increased significantly during the storage period in these conditions. At the end of freeze-drying, moisture content for freeze-dried $L$. mesenteroides or L. plantarum $\mathrm{P}$ and $\mathrm{PC}$ was $3.6 \pm 0.7 \%$ and $4.8 \pm 0.5 \%$ or $3.1 \pm 0.3 \%$ and $4.7 \pm 0.7 \%$ with $a_{\mathrm{w}} 0.1 \pm 0.01$ for each batch type. After a 90-day storage, water content for freeze-dried L. mesenteroides or L. plantarum P and PC increased to $20.2 \pm 0.4 \%$ and $21.6 \pm$ $0.3 \%$ or $19.4 \pm 0.8 \%$ and $21.8 \pm 0.2 \%$ at $4{ }^{\circ} \mathrm{C}$, to $11.4 \pm 0.7 \%$ and $16.9 \pm 1.1 \%$ or $12.1 \pm 1.1 \%$ and $15.4 \pm 0.4 \%$ at $20^{\circ} \mathrm{C}$, respectively (Tables 4,5 , and 6 ). During the same time, $a_{\mathrm{w}}$ increases to $0.6 \pm 0.01$ and $0.6 \pm 0.01$ or $0.6 \pm 0.01$ and $0.6 \pm 0.01$ at $4{ }^{\circ} \mathrm{C}$, to $0.4 \pm 0.01$ and $0.4 \pm 0.01$ or $0.4 \pm 0.01$ and $0.4 \pm 0.01$ at $20^{\circ} \mathrm{C}$, respectively.

The rate of dry matter in a lyophilized powder, which is nearly $94 \%$, and a water activity less than 0.2 would be necessary to ensure a level of storage stability at room temperature. These conditions are consistent with research undertaken by French's Patent FR No. 2829147 [23], which stipulates that in a dried product the following parameters: very low water activity $(<0.2)$, rate of dry matter around $96 \%$ and a $T_{\mathrm{g}}=T_{\mathrm{s}}-25{ }^{\circ} \mathrm{C}>20^{\circ} \mathrm{C}$, contribute to the stability of the product for an extended period during the storage

\section{Survival of Lactic L. mesenteroides and L. plantarum during Storage}

These authors $[23,24]$ showed that stability of dried lactic acid bacteria upon storage was better in the $0.1-0.2 a_{\mathrm{w}}$ zone. In this study, the water activity of strains after freeze drying have some $a_{\mathrm{w}}$ less than 0.170 at $25{ }^{\circ} \mathrm{C}$ (data are not shown). This result shows that the lactic acid bacteria are well lyophilized. Figures 1 and 2 show the survival of freeze-dried L. mesenteroides and L. plantarum during the storage period, respectively. In vacuum-

Fig. 1 Survival of freeze-dried L. mesenteroides during storage at $4{ }^{\circ} \mathrm{C}$ or $20^{\circ} \mathrm{C}$. Symbols: open circle, freeze-dried strain without cryoprotectants $(\mathrm{P})$; filled circle, freeze-dried strain with cryoprotectants $(5 \%$ maltodextrine $+2 \%$ glycerol) (PC). Dotted lines for storage in vacuum-sealed aluminum foil, continuous lines for storage in opened white glass tube. Values represent means $\pm \mathrm{SD}(n=4)$

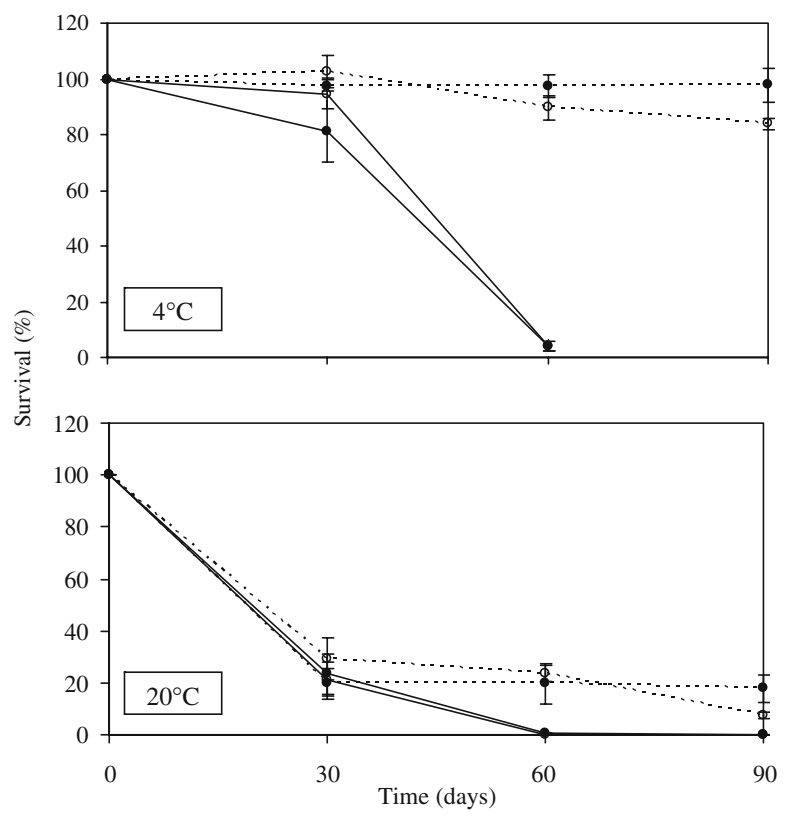


Fig. 2 Survival of freeze-dried L. plantarum during storage at $4{ }^{\circ} \mathrm{C}$ or $20^{\circ} \mathrm{C}$. Symbols: open circle, freeze-dried strain without cryoprotectants $(\mathrm{P})$; filled circle, freeze-dried strain with cryoprotectants $(5 \%$ maltodextrine $+2 \%$ glycerol) (PC). Dotted lines for storage in vacuum-sealed aluminum foil, continuous lines for storage in opened white glass tube. Values represent means $\pm \mathrm{SD}(n=4)$

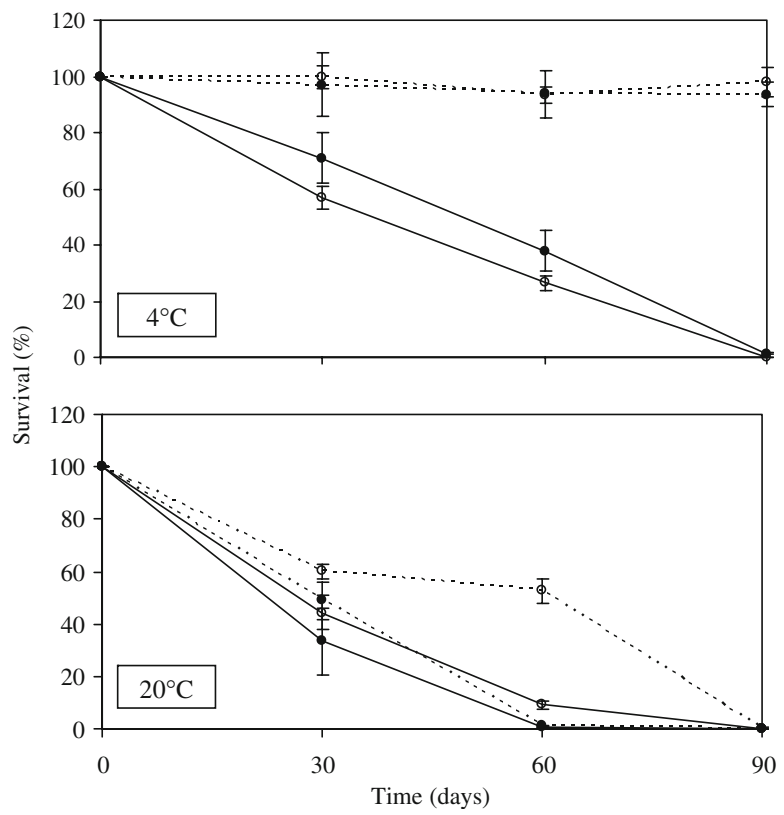

sealed aluminum foil and open white glass tube at $4{ }^{\circ} \mathrm{C}$ and $20{ }^{\circ} \mathrm{C}$. Table 4 shows a summary of the survival of test organisms and water content of the freeze-dried powder under different packaging and storage temperature after a 90-day storage. It was found that regardless of packaging mode and storage temperatures, the viable cells of $L$. mesenteroides (Fig. 1) and L. plantarum (Fig. 2), added or not with cryoprotectants, decreased as the storage time increased. However, a higher viable population of $L$. mesenteroides and $L$. plantarum was noted in the freeze-dried powder held at $4{ }^{\circ} \mathrm{C}$ or under vacuum and in the dark than at $20{ }^{\circ} \mathrm{C}$ or in presence of air and light. For example, the viable population of $L$. plantarum with cryoprotectants held in vacuum-sealed aluminum foil or open white glass tube was reduced from an initial population of 11.65 to $11.72 \log \mathrm{CFU} / \mathrm{g}$ or $9.88 \mathrm{log} \mathrm{CFU} / \mathrm{g}$ with no population reduction or a reduction of only $1.77 \log \mathrm{CFU} / \mathrm{g}$ and a survival percentage of $93.5 \%$ or $1.4 \%$ after a 90 -day storage at $4{ }^{\circ} \mathrm{C}$ (Fig. 2, Table 4 ) compared to a larger population reduction of $2.64 \mathrm{log} \mathrm{CFU} / \mathrm{g}$ or $4.68 \mathrm{log} \mathrm{CFU} / \mathrm{g}$ and a less survival of $0.19 \%$ or less than $0.1 \%$ at $20^{\circ} \mathrm{C}$, respectively. As shown in Figs. 1 and 2 and Table 4 , it was noted that for either L. mesenteroides or L. plantarum there was no significant effect of cryoprotectants on survival after a 90 -day storage.

The powder produced from L. plantarum and L. mesentoïdes meet all these conditions and yet conservation is not optimal during storage except that the survival rate of $L$. plantarum is slightly higher than L. mesentorides. This difference between the two freezedried bacteria during storage finds its origin in the structure of the cells. Apart from this, freeze-dried powders meet the above-mentioned criteria and yet the survival rate is not high during storage. According to the work of [26], a number of factors can influence the percentage of survival in function of time. With regard to the other predominant factors to this loss of viability, one could cite (the water activity), probably taken into contained pure water powders, the effect of temperature and light for hermetically sealed bags (under vacuum) containing 2-3 g of powder. Loss of viability was also noted that at this level find its origin by the combined effect of temperature and oxidation of cellular constituents as 
Table 2 Cellular fatty acid composition of L. mesenteroides before and after freeze-drying.

\begin{tabular}{llllllll}
\hline Treatment $^{\mathrm{a}}$ & \multicolumn{7}{l}{ Relative content $(\%)^{\mathrm{b}}$} \\
\cline { 2 - 8 } & & $\mathrm{C} 16: 0$ & $\mathrm{C} 16: 1$ & $\mathrm{C} 18: 0$ & $\mathrm{C} 18: 1$ & $\mathrm{C} 18: 2$ & $\mathrm{C} 18: 3$ \\
\hline Before freeze-drying & $\mathrm{P}$ & $49.7 \pm 0.7 \mathrm{ab}^{1}$ & $7.4 \pm 0.1 \mathrm{a}$ & $8.5 \pm 0.1 \mathrm{a}$ & $28.9 \pm 0.8 \mathrm{a}$ & $1.0 \pm 0.1 \mathrm{a}$ & $4.5 \pm 0.1 \mathrm{a}$ \\
& PC & $50.3 \pm 0.1 \mathrm{ab}$ & $6.3 \pm 0.7 \mathrm{a}$ & $7.9 \pm 0.1 \mathrm{a}$ & $30.0 \pm 0.9 \mathrm{a}$ & $1.0 \pm 0.2 \mathrm{a}$ & $4.5 \pm 0.3 \mathrm{a}$ \\
After freeze-drying & P & $48.6 \pm 1.3 \mathrm{a}$ & $7.9 \pm 0.7 \mathrm{a}$ & $8.7 \pm 1.6 \mathrm{a}$ & $29.3 \pm 1.6 \mathrm{a}$ & $1.1 \pm 0.1 \mathrm{a}$ & $4.5 \pm 0.2 \mathrm{a}$ \\
& PC & $53.1 \pm 1.1 \mathrm{~b}$ & $6.8 \pm 0.1 \mathrm{a}$ & $7.7 \pm 0.2 \mathrm{a}$ & $26.9 \pm 1.3 \mathrm{a}$ & $0.8 \pm 0.1 \mathrm{a}$ & $4.7 \pm 0.3 \mathrm{a}$ \\
\hline
\end{tabular}

The six main fatty acids are palmitic (C16:0), palmitoleic (C16:1), stearic (C 18:0), oleic (C 18:1), linoleic (C 18:2), linolenic (C 18:3)

${ }^{\text {a }} \mathrm{P}$, cells without cryoprotectants; PC, cells with cryoprotectants ( $5 \%$ maltodextrine, $2 \%$ glycerol)

${ }^{\mathrm{b}}$ Values are means $\pm \mathrm{SD}(n=4)$ and represent proportions of total fatty acids $(\%)$

${ }^{1}$ Values in the same column with different letters are significantly different $(p<0.05)$.

unsaturated fatty acids [34]. This oxidation finds its source by oxygen effect, lyophilized powders that create free radicals. These free radicals are toxic substances that lead to rupture the membrane and thus cellular cell death in the future. These primarily mitigate the adverse events and are especially responsible for significant losses during storage that biologists increasingly need antioxidant to stop or reduce the oxidation products at the level of freeze-dried powders. It is safe to say that based on our experiences and those of others, the loss of viability during storage is subject to a phenomenon of autooxidation, which should optimize the survival rate especially during storage at room temperature. The important and intrinsic parameters (dry cell matter, water activity) merit attention while optimizing for the increase and prolonged time storage of lyophilized powders of lactic acid bacteria. For this reason and many others, some authors argue that the cell membrane is the seat of the cell survival in the sense that it contains phospholipids that are probably modified by the oxidation [26].

Cellular Fatty Acid Relative Contents after Freeze-Drying and Changes in Fatty Acid Composition Due to Storage

Cellular fatty acids (CFAs) from the two strains were analyzed before and after freezedrying. The mean relative contents of CFAs from L. mesenteroides and L. plantarum are

Table 3 Cellular fatty acid composition of L. plantarum before and after freeze-drying.

\begin{tabular}{llllllll}
\hline Treatment $^{\mathrm{a}}$ & \multicolumn{7}{l}{ Relative content $(\%)^{\mathrm{b}}$} \\
\cline { 2 - 8 } & & $\mathrm{C} 16: 0$ & $\mathrm{C} 16: 1$ & $\mathrm{C} 18: 0$ & $\mathrm{C} 18: 1$ & $\mathrm{C} 18: 2$ & $\mathrm{C} 18: 3$ \\
\hline Before freeze-drying & $\mathrm{P}$ & $55.0 \pm 0.7 \mathrm{a}^{1}$ & $7.4 \pm 0.1 \mathrm{a}$ & $7.9 \pm 0.6 \mathrm{a}$ & $22.7 \pm 0.8 \mathrm{a}$ & $1.1 \pm 0.2 \mathrm{a}$ & $6.0 \pm 0.9 \mathrm{a}$ \\
& PC & $54.3 \pm 0.9 \mathrm{a}$ & $7.9 \pm 1.0 \mathrm{a}$ & $8.4 \pm 0.4 \mathrm{a}$ & $22.7 \pm 0.5 \mathrm{a}$ & $1.0 \pm 0.1 \mathrm{a}$ & $5.8 \pm 0.7 \mathrm{a}$ \\
After freeze-drying & P & $55.2 \pm 1.3 \mathrm{a}$ & $6.2 \pm 0.1 \mathrm{a}$ & $8.1 \pm 0.9 \mathrm{a}$ & $23.9 \pm 0.6 \mathrm{a}$ & $0.8 \pm 0.1 \mathrm{a}$ & $5.8 \pm 0.3 \mathrm{a}$ \\
& PC & $53.6 \pm 0.7 \mathrm{a}$ & $7.0 \pm 1.2 \mathrm{a}$ & $9.7 \pm 0.3 \mathrm{a}$ & $23.2 \pm 0.1 \mathrm{a}$ & $0.8 \pm 0.1 \mathrm{a}$ & $5.7 \pm 0.2 \mathrm{a}$ \\
\hline
\end{tabular}

The six main fatty acids are palmitic (C16:0), palmitoleic (C16:1), stearic (C 18:0), oleic (C 18:1), linoleic (C 18:2), linolenic (C 18:3)

${ }^{\mathrm{a}} \mathrm{P}$, cells without cryoprotectants; PC, cells with cryoprotectants (5\% maltodextrine, $2 \%$ glycerol)

${ }^{\mathrm{b}}$ Values are means $\pm \mathrm{SD}(n=4)$ and represent proportions of total fatty acids $(\%)$

${ }^{1}$ Values in the same column with the same letter are not significantly different $(p>0.05)$. 
presented in Tables 2 and 3, respectively. Six CFAs, namely palmitic $\left(\mathrm{C}_{16: 0}\right)$, palmitoleic $\left(\mathrm{C}_{16: 1}\right)$, stearic $\left(\mathrm{C}_{18: 0}\right)$, oleic $\left(\mathrm{C}_{18: 1}\right)$, linoleic $\left(\mathrm{C}_{18: 2}\right)$, and linolenic $\left(\mathrm{C}_{18: 3}\right)$ acids were identified. Four of the CFAs, namely $C_{16: 0}, C_{16: 1}, C_{18: 0}$, and $C_{18: 1}$, make up more than $94 \%$ or $93 \%$ of the fatty acids in L. mesenteroides and L. plantarum respectively, with another one, namely, $\mathrm{C}_{18: 3}$ making a smaller (on average 5-6\%, respectively) contribution. The
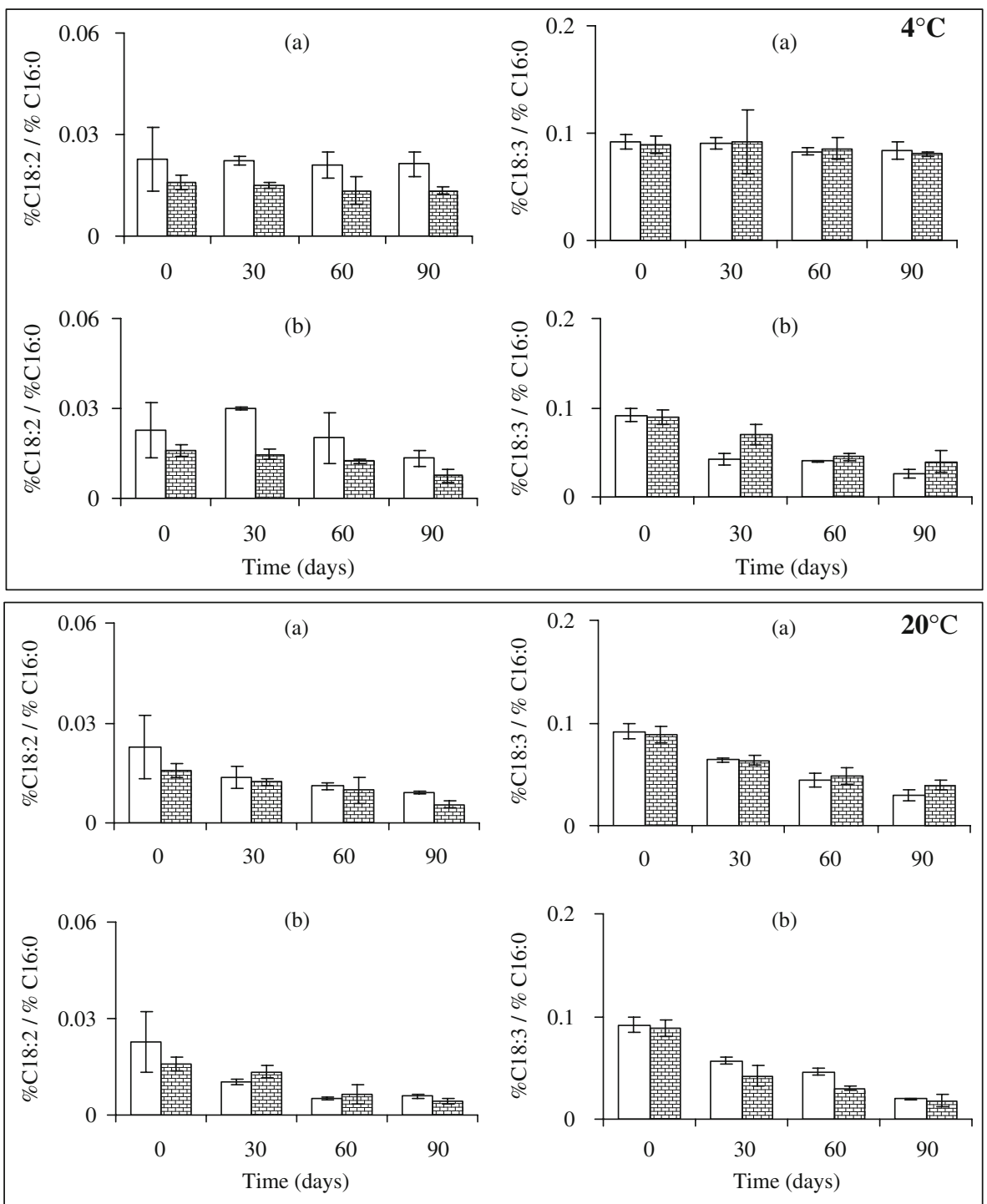

\section{$\square$ Cells without cryoprotectants \\ 圈 Cells with cryoprotectants (5\% maltodextrine $+2 \%$ glycerol)}

Fig. $3 \mathrm{C} 18: 2 / \mathrm{C} 16: 0$ and $\mathrm{C} 18: 3 / \mathrm{C} 16: 0$ ratios of freeze-dried $L$. mesenteroides during 90-day storage at: $4{ }^{\circ} \mathrm{C}$ (A) or $20{ }^{\circ} \mathrm{C}$ (B) in vacuum-sealed aluminum foil (a) or in open white glass tube (b). Bars are means \pm SD $(n=4)$ and represent the ratio between each fatty acid and the palmitic $(\mathrm{C} 16: 0)$ acid 
$\mathrm{C}_{18: 2}$ represent very small percentages (on mean $\leq 1 \%$ ) to the total in each strain. $\mathrm{C}_{16: 0}$ had the highest proportion. There was no significant modification in CFAs of L. mesenteroides and L. plantarum in response to dehydratation $(p>0.05)$. Moreover, the addition of glycerol and maltodextrine before freeze drying did not modify significantly the CFAs of the two strains.

Cellular fatty acids freeze-dried of L. mesenteroides and L. plantarum packaged in vacuum-sealed aluminum foil or opened white glass tube and held at 20 or $4{ }^{\circ} \mathrm{C}$ during
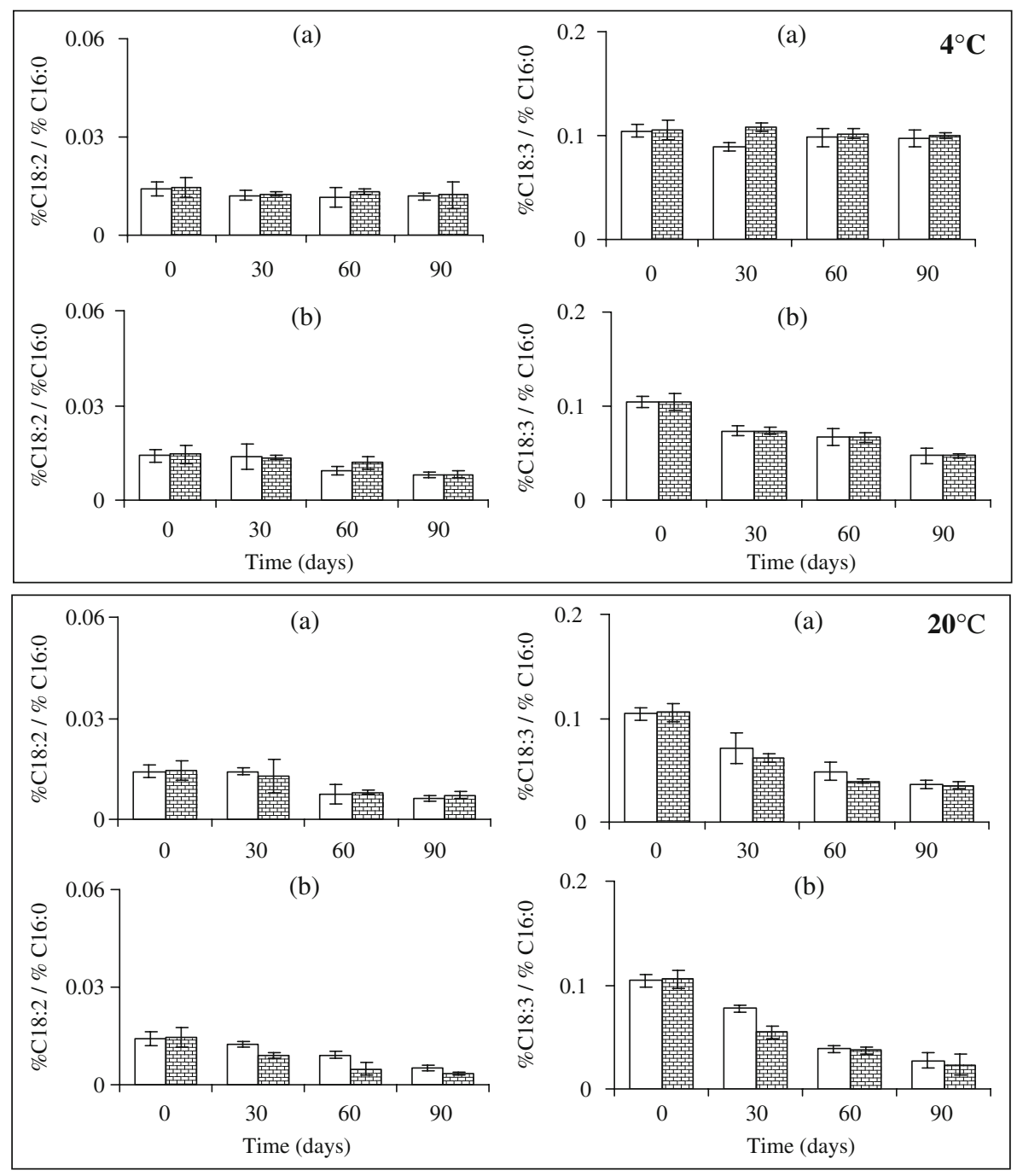

$\square$ Cells without cryoprotectants

畊Cells with cryoprotectants $(5 \%$ maltodextrine $+2 \%$ glycerol)

Fig. $4 \mathrm{C} 18: 2 / \mathrm{C} 16: 0$ and $\mathrm{C} 18: 3 / \mathrm{C} 16: 0$ ratios of freeze-dried $L$. plantarum during 90-day storage at: $4{ }^{\circ} \mathrm{C}(\mathrm{A})$ or $20{ }^{\circ} \mathrm{C}(\mathrm{B})$ in vacuum-sealed aluminum foil (a) or in open white glass tube (b). Bars are means \pm SD $(n=4)$ and represent the ratio between each fatty acid and the palmitic (C16:0) acid 


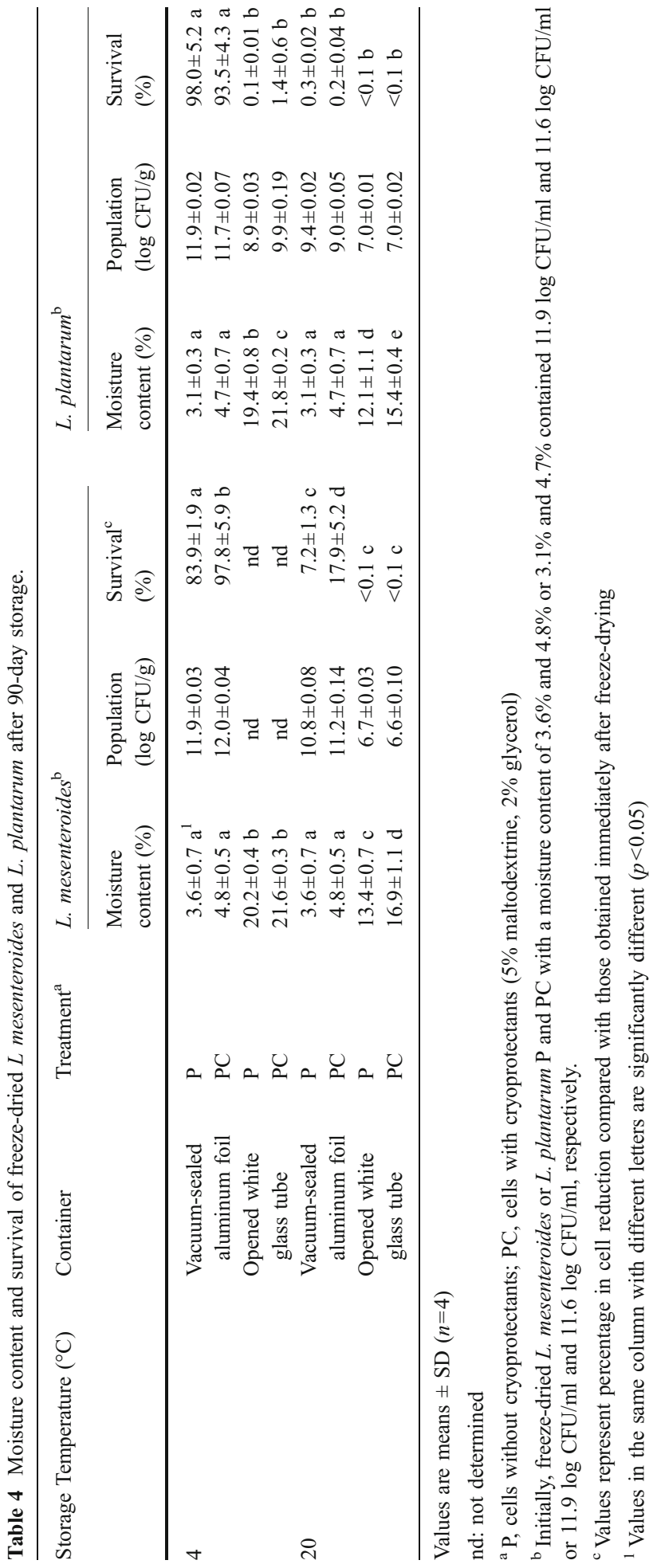


90 days were analyzed. The palmitic acid $\left(\mathrm{C}_{16: 0}\right)$ relative content remained high and changed only little during storage. Therefore, the content of the others fatty acids was expressed as a ratio between each fatty acid and the $C_{16: 0}$. It was observed that $C_{16: 1} / C_{16: 0}$, $\mathrm{C}_{18: 0} / \mathrm{C}_{16: 0}$ and $\mathrm{C}_{18: 1} / \mathrm{C}_{16: 0}$ ratios for freeze-dried L. mesenteroides or L. plantarum, added or not with cryoprotectants did not change significantly during the storage period. Figures 3 and 4 show linoleic/palmitic $\left(\mathrm{C}_{8: 2} / \mathrm{C}_{16: 0}\right)$ or linolenic/ palmitic $\left(\mathrm{C}_{18: 3} / \mathrm{C}_{16: 0}\right)$ ratios for freeze-dried $L$. mesenteroides and $L$. plantarum during the storage period, respectively. Tables 5 and 6 show a summary of linoleic/palmitic $\left(\mathrm{C}_{18: 2} / \mathrm{C}_{16: 0}\right)$ and linolenic/palmitic $\left(\mathrm{C}_{18: 3} / \mathrm{C}_{16: 0}\right)$ ratios for freeze-dried organisms under different packaging and storage temperature after a 90-day storage, respectively. It was found that regardless of packaging mode and storage temperatures, $\mathrm{C}_{18: 2} / \mathrm{C}_{16: 0}$ and $\mathrm{C}_{18: 3} / \mathrm{C}_{16: 0}$ ratios for freeze-dried $L$. mesenteroides (Fig. 3) and L. plantarum (Fig. 4) added or not with cryoprotectants decreased in function of time. However, a higher $\mathrm{C}_{18: 2} / \mathrm{C}_{16: 0}$ or $\mathrm{C}_{18: 3} / \mathrm{C}_{16: 0}$ ratio for $L$. mesenteroides and L. plantarum was noted in the freeze-dried powder held at $4{ }^{\circ} \mathrm{C}$ or under vacuum and in the dark than at $20{ }^{\circ} \mathrm{C}$ or in the presence of air and light (Table 4). For example, $\mathrm{C}_{18: 2} / \mathrm{C}_{16: 0}$ and $\mathrm{C}_{18: 3} / \mathrm{C}_{16: 0}$ ratios were 0.01 and 0.11 for freeze-dried L. plantarum with cryoprotectants at the end of freeze-drying, respectively (Tables 5 and 6). After a 90-day storage in vacuum-sealed aluminum foil or open white glass tube, $C_{18: 2} / C_{16: 0}$ ratio decreased from the original value by $0 \%$ or $19.0 \%$ with a ratio reduction of only 0 or 0.002

Table 5 Moisture content and C18:2/C16:0 ratio for freeze-dried L mesenteroides and L. plantarum after 90 -day storage.

\begin{tabular}{|c|c|c|c|c|c|c|c|c|}
\hline \multicolumn{2}{|l|}{ Storage } & \multirow[t]{2}{*}{ Treatment $^{\mathrm{a}}$} & \multicolumn{3}{|c|}{ L. mesenteroides ${ }^{\mathrm{c}}$} & \multicolumn{3}{|c|}{ L. plantarum $^{\mathrm{c}}$} \\
\hline $\begin{array}{l}\text { Temperature } \\
\left({ }^{\circ} \mathrm{C}\right)\end{array}$ & Container & & $\begin{array}{l}\text { Moisture } \\
\text { content }(\%)\end{array}$ & $\begin{array}{l}\text { Ratio }^{\mathrm{b}} \\
(\%)\end{array}$ & $(\%)^{d}$ & $\begin{array}{l}\text { Moisture } \\
\text { content } \\
(\%)\end{array}$ & $\begin{array}{l}\text { Ratio }^{\mathrm{b}} \\
(\%)\end{array}$ & $(\%)$ \\
\hline \multirow[t]{4}{*}{4} & \multirow{2}{*}{$\begin{array}{l}\text { Vacuum- } \\
\text { sealed } \\
\text { aluminum } \\
\text { foil }\end{array}$} & $\mathrm{P}$ & $3.6 \pm 0.7 \mathrm{a}^{1}$ & 2.13 & $86.4 \pm 1.3$ & $3.1 \pm 0.3 \mathrm{a}$ & 1.19 & $83.9 \pm 5.7$ \\
\hline & & $\mathrm{PC}$ & $4.8 \pm 0.5 \mathrm{a}$ & 1.35 & $85.3 \pm 0.8$ & $4.7 \pm 0.7 \mathrm{a}$ & 1.22 & $122.0 \pm 8.3$ \\
\hline & \multirow{2}{*}{$\begin{array}{l}\text { Opened } \\
\text { white } \\
\text { glass tube }\end{array}$} & $\mathrm{P}$ & $20.2 \pm 0.4 \mathrm{~b}$ & 1.35 & $57.8 \pm 1.8$ & $19.4 \pm 0.8 \mathrm{~b}$ & 0.81 & $56.9 \pm 1.4$ \\
\hline & & $\mathrm{PC}$ & $21.6 \pm 0.3 \mathrm{~b}$ & 0.75 & $47.5 \pm 0.9$ & $21.8 \pm 0.2 \mathrm{c}$ & 0.81 & $81.0 \pm 7.5$ \\
\hline \multirow[t]{4}{*}{20} & \multirow{2}{*}{$\begin{array}{l}\text { Vacuum- } \\
\text { sealed } \\
\text { aluminum } \\
\text { foil }\end{array}$} & $\mathrm{P}$ & $3.6 \pm 0.7 \mathrm{a}$ & 0.90 & $37.8 \pm 2.2$ & $3.1 \pm 0.3 \mathrm{a}$ & 0.63 & $44.7 \pm 2.4$ \\
\hline & & $\mathrm{PC}$ & $4.8 \pm 0.5 \mathrm{a}$ & 0.54 & $34.4 \pm 0.4$ & $4.7 \pm 0.7 \mathrm{a}$ & 0.72 & $71.9 \pm 3.3$ \\
\hline & \multirow{2}{*}{$\begin{array}{l}\text { Opened } \\
\text { white } \\
\text { glass tube }\end{array}$} & $\mathrm{P}$ & $13.4 \pm 0.7 \mathrm{c}$ & 0.59 & $23.9 \pm 5.9$ & $12.1 \pm 1.1 \mathrm{~d}$ & 0.53 & $37.1 \pm 0.7$ \\
\hline & & $\mathrm{PC}$ & $16.9 \pm 1.1 \mathrm{~d}$ & 0.43 & $27.0 \pm 4.0$ & $15.4 \pm 0.4 \mathrm{e}$ & 0.35 & $35.3 \pm 3.4$ \\
\hline
\end{tabular}

Values are means $\pm \mathrm{SD}(n=4)$.

${ }^{\text {a }} \mathrm{P}$, cell without cryoprotectants; PC, cell with cryoprotectants (5\% maltodextrine, $2 \%$ glycerol)

${ }^{\mathrm{b}}$ Values represent ratio between each fatty acid and the palmitic acid

${ }^{\mathrm{c}}$ Initially, freeze-dried L. mesenteroides or L. plantarum $\mathrm{P}$ and $\mathrm{PC}$ with a moisture content of $3.6 \%$ and $4.8 \%$ or $3.1 \%$ and $4.7 \%$ contained 0.03 of $\mathrm{C} 16: 0$ and 0.02 of $\mathrm{C} 16: 0$ or 0.01 of $\mathrm{C} 16: 0$ and 0.01 of $\mathrm{C} 16: 0$, respectively

${ }^{\mathrm{d}}$ Values represent percentage compared to the initial ratio

${ }^{1}$ Values in the same column with different letters are significantly different $(p<0.05)$ 
Table 6 Moisture content and C18:3/C16:0 ratio for freeze-dried L mesenteroides and L. plantarum after 90 -day storage.

\begin{tabular}{|c|c|c|c|c|c|c|c|c|}
\hline \multicolumn{2}{|l|}{ Storage } & \multirow[t]{2}{*}{ Treatment $^{\mathrm{a}}$} & \multicolumn{3}{|c|}{ L. mesenteroides ${ }^{\mathrm{c}}$} & \multicolumn{3}{|c|}{ L. plantarum $^{\mathrm{c}}$} \\
\hline $\begin{array}{l}\text { Temperature } \\
\left({ }^{\circ} \mathrm{C}\right)\end{array}$ & Container & & $\begin{array}{l}\text { Moisture } \\
\text { content }(\%)\end{array}$ & $\begin{array}{l}\text { Ratio }^{b} \\
(\%)\end{array}$ & $(\%)^{d}$ & $\begin{array}{l}\text { Moisture } \\
\text { content } \\
(\%)\end{array}$ & $\begin{array}{l}\text { Ratio }^{\mathrm{b}} \\
(\%)\end{array}$ & $(\%)$ \\
\hline \multirow[t]{4}{*}{4} & \multirow{4}{*}{$\begin{array}{l}\text { Vacuum-sealed } \\
\text { aluminum foil } \\
\text { Opened } \\
\text { white glass tube }\end{array}$} & $\mathrm{P}$ & $3.6 \pm 0.7 \mathrm{a}^{1}$ & 8.4 & $88.1 \pm 2.4$ & $3.1 \pm 0.3 \mathrm{a}$ & 9.8 & $92.9 \pm 1.2$ \\
\hline & & $\mathrm{PC}$ & $4.8 \pm 0.5 \mathrm{a}$ & 8.1 & $93.1 \pm 2.6$ & $4.7 \pm 0.7 \mathrm{a}$ & 10.0 & $95.2 \pm 6.9$ \\
\hline & & $\mathrm{P}$ & $20.2 \pm 0.4 \mathrm{~b}$ & 2.6 & $27.3 \pm 2.9$ & $19.4 \pm 0.8 \mathrm{~b}$ & 4.7 & $44.7 \pm 3.2$ \\
\hline & & $\mathrm{PC}$ & $21.6 \pm 0.3 b$ & 3.9 & $44.4 \pm 8.5$ & $21.8 \pm 0.2 \mathrm{c}$ & 5.0 & $47.3 \pm 0.2$ \\
\hline \multirow[t]{4}{*}{20} & \multirow{2}{*}{$\begin{array}{l}\text { Vacuum-sealed } \\
\text { aluminum foil }\end{array}$} & $\mathrm{P}$ & $3.6 \pm 0.7 \mathrm{a}$ & 2.9 & $31.3 \pm 3.5$ & $3.1 \pm 0.3 \mathrm{a}$ & 3.6 & $34.1 \pm 1.7$ \\
\hline & & $\mathrm{PC}$ & $4.8 \pm 0.5 \mathrm{a}$ & 3.9 & $44.2 \pm 6.8$ & $4.7 \pm 0.7 \mathrm{a}$ & 3.5 & $33.9 \pm 5.1$ \\
\hline & \multirow{2}{*}{$\begin{array}{l}\text { Opened white } \\
\text { glass tube }\end{array}$} & $\mathrm{P}$ & $13.4 \pm 0.7 \mathrm{c}$ & 2.0 & $21.7 \pm 2.7$ & $12.1 \pm 1.1 \mathrm{~d}$ & 2.7 & $25.9 \pm 0.7$ \\
\hline & & $\mathrm{PC}$ & $16.9 \pm 1.1 \mathrm{~d}$ & 1.8 & $20.3 \pm 4.1$ & $15.4 \pm 0.4 \mathrm{e}$ & 2.3 & $22.0 \pm 2.7$ \\
\hline
\end{tabular}

Values are means $\pm \operatorname{SD}(n=4)$.

${ }^{\mathrm{a}} \mathrm{P}$, cell without cryoprotectants; PC, cell with cryoprotectants (5\% maltodextrine, $2 \%$ glycerol)

${ }^{\mathrm{b}}$ Values represent ratio between each fatty acid and the palmitic acid

${ }^{\mathrm{c}}$ Initially, freeze-dried L. mesenteroides or L. plantarum $\mathrm{P}$ and $\mathrm{PC}$ with a moisture content of $3.6 \%$ and $4.8 \%$ or $3.1 \%$ and $4.7 \%$ contained 0.10 of $\mathrm{C} 16: 0$ and 0.09 of $\mathrm{C} 16: 0$ or 0.11 of $\mathrm{C} 16: 0$ and 0.11 of $\mathrm{C} 16: 0$ for $\mathrm{P}$ and $\mathrm{PC}$, respectively

${ }^{\mathrm{d}}$ Values represent percentage compared to the initial ratio

${ }^{1}$ Values in the same column with different letters are significantly different $(p<0.05)$

at $4{ }^{\circ} \mathrm{C}$ (Fig. 3, Table 5) compared to a larger decreased from the original value by $28.1 \%$ or $64.71 \%$ with a ratio reduction of 0.003 or 0.007 at $20{ }^{\circ} \mathrm{C}$, respectively. During the same time $\mathrm{C}_{18: 3} / \mathrm{C}_{16: 0}$ ratio decreased from the original value by $4.8 \%$ or $52.7 \%$ with a ratio reduction of only 0.010 or 0.060 at $4{ }^{\circ} \mathrm{C}$ (Fig. 3, Table 6) compared to a larger decreased from the original value by $66.1 \%$ or $78.0 \%$ with a ratio reduction of only 0.075 or 0.087 at $20{ }^{\circ} \mathrm{C}$, respectively. In most cases, after 90 -day storage, the decreased in $\mathrm{C}_{18: 2} / \mathrm{C}_{16: 0}$ ratio was less than that in $\mathrm{C}_{18: 3} / \mathrm{C}_{16: 0}$ ratio (Tables 5 and 6). $\mathrm{C}_{18: 2} / \mathrm{C}_{16: 0}$ and $\mathrm{C}_{18: 3} / \mathrm{C}_{16: 0}$ ratios for freeze-dried strains added with or without cryoprotectants are not significantly different after 90-day storage $(p>0.05)$.

Lipid oxidation and specially lipids of membrane fatty acid was probably deemed responsible for cell death during storage $[9,6]$. Cellular fatty acids of $L$. mesenteroides and L. plantarum consisted of: palmitic, palmitoleic, stearic, oleic, linoleic, and linolenic. All these acids have been identified previously in cellular membrane of acetic acid bacteria and lactic acid bacteria [27, 28] ratios. Contrarily to their saturated and unsaturated analogs, polyunsaturated fatty acids (PUFAs) are much more susceptible to oxidation [25, 28]. After 90 days, $\mathrm{C}_{18: 2} / \mathrm{C}_{16: 0}$ and $\mathrm{C}_{18: 3} / \mathrm{C}_{16: 0}$ ratios were significantly lower for both freeze-dried strain held in open glass tube at $20^{\circ} \mathrm{C}$. The effect of temperature during storage on freezedried powder is harmful to microorganisms' survival. What concern light, its action is detrimental and leads to decrease the survival rate. Upon exposure to combined light, temperature, and oxygen, a cooperative, deleterious effect was noted resulting in an even higher loss in viability. A possible interpretation is that under these conditions linoleic and linolenic acids can be further rapidly converted to hydroperoxides [29-30]. This is supported by the fact that, during storage in opened white glass tube at $4{ }^{\circ} \mathrm{C}$ and in vacuumsealed aluminum foil at $20{ }^{\circ} \mathrm{C} \mathrm{C}_{18: 2} / \mathrm{C}_{16: 0}$ and $\mathrm{C}_{18: 3} / \mathrm{C}_{16: 0}$ ratios decrease more slowly. The occurrence of many of these compounds has been explained on the basis of the formation 
and/or combination of free radicals resulting from homolytic cleavage of $\mathrm{C}-\mathrm{C}$ linkages near the double bound. Thus, linoleic and linolenic acids degradation may not be dependant on the presence or absence of free molecular oxygen but on the presence of reactive free radicals in the dried matrix. Linolenic acid was degraded faster than linoleic acid and even in cell membrane, as previous studies have shown, an unsaturated fatty acid with more double bounds (and/or conjugated double bonds) would be more easily oxidized [31]. Our results strongly point toward the possibility that the loss of water during freeze-drying process generates an oxidative stress. Pereira et al., (2003) reported also that freeze-dried cells showed increase in oxidation during storage. However, the origin of free radicals during dehydratation remains unknown [32]. The influence of temperature during storage of unsaturated fatty acids in the absence of oxygen, dimeric compounds and substances of lower molecular weight are more likely to be produced [33].

\section{Conclusion}

The results presented here provide experimental support to the hypothesis that storage in the presence of air, high moisture content, and high temperature is detrimental to freezedried powders. Low survival during storage was associated with a decrease in C18:2/C16:0 and $\mathrm{C} 18: 3 / \mathrm{C} 16: 0$ ratios. Our results confirm the importance controlling temperature, atmosphere, and residual water activity of dried cultures to optimize survival. These data further support the view that PUFAs (linoleic and linolenic acids) play a key role in determining cellular susceptibility to oxidative and/or heat stress. The beneficial effect of the use of cryoprotectants is associated clearly with high viability after freeze-dying rather than increased stability during storage. Further attempts to stabilize freeze-dried cells during storage must be made, and the addition of compounds that interact with the cytoplasmic membrane could be explored. Detection of linoleic or linolenic acids degradation byproducts will allow having a correct picture of lipid degradation proceeds.

Acknowledgments The authors would like to acknowledge the Federal Research Centre for Nutrition, Institute of Hygiene and Toxicology, Karlsruhe, Germany for providing L. mesenteroides ssp. mesenteroides Kenya MRog2 strain and Mrs Maryse Hardenne and Mr Philippe Mottet for their contribution. We thank all the technical personal of CWBI (Centre Wallon de Biologie Industrielle). We also express our gratitude to the republic of Ivory Cost and the communauté française de Belgique for financial assistance.

\section{References}

1. Kostinek, M., Specht, I., Edward, V. A., Schillinger, U., Hertel, C., Holzapfel, W. H., et al. (2005). Systematic and Applied Microbiology, 28, 527-540.

2. Carvalho, A. S., Silva, J. H., Teixera, P., Malcata, F. X., \& Gibbs, P. (2003). International Dairy Journal, 13, 463-468.

3. Fonseca, F., Béal, C., \& Corrieu, J. (2000). Journal of Dairy Research, 67, 83-90.

4. Béal, C., Mihoub, F., Marin, M., \& Corrieu, G. (2001) Demande de Brevet d'invention FR N²829147.

5. Champagne, C. P., Detournay, H., \& Hardy, M. J. (1991). Journal of Industrial Microbiology, 7, 147150 .

6. Teixeira, P. C., Castro, M. H., \& Kirby, R. M. (1996). Letters in Applied Microbiology, 22, 34-38.

7. Pereira, E. J., Panek, A. D., \& Eleutherio, E. C. A. (2003). Cell Stress Chaperones, 8, 120-124.

8. Hansen, J. M., Go, Y. M., \& Jones, D. P. (2006). Annual Review of Pharmacology and Toxicology, 46, $215-234$.

9. Teixeira, P. C., Castro, M. H., Malcata, F. X., \& Kirby, R. M. (1995). Journal of Dairy Science, 78, 1025-1031. 
10. Dimmick, R. L., \& Heckly, R. J. (1987). Nature, 192, 776.

11. Marshall, B. J., Goote, G. G., \& Scott, W. J. A. (1974). Study of factors affecting the survival of dried bacteria during storage. Technical Paper, CSIRO Australian Div Food Res, 39, 1-29.

12. Pryor, W. A. (1971). Chemical \& Engineering News, 49, 34-51.

13. Girotti, A. W., \& Thomas, J. P. (1984). Journal of Biological Chemistry, 259, 17-44.

14. Halverson, L. J., \& Firestone, M. K. (2000). Applied and Environmental Microbiology, 66, 2114-2421.

15. Théberge, M. C., Prévost, D., \& Chalifour, F. P. (1996). New Phytologist, 134, 657-664.

16. Andersen, A. B., Fog-Petersen, M. S., Larsen, H., \& Skibsted, L. H. (1999). Lebensmittel-Wissenschaft and Technologie, 32, 540-547.

17. Hamoudi, L., Goulet, J., \& Ratti, C. (2007). Effect of protective agents on the viability of Geotricum candidum during freeze-drying and storage. Food Microbial Safety, 72, 45-49.

18. Cronan Jr., J. E., \& Zhang, Y (1998). Journal of Bacteriology, 180, 3295-3303.

19. Suzuki, K., Goodfellow, M., \& O’Donnell, A. G. (1993). Cell envelopes and classification. In M. Goodfellow \& A. G. O’Donnell (Eds.), Handbook of New Bacterial Systematics (pp. 195-250). London: Academic Press.

20. Kieft, T. L., Ringleberg, D. B., \& White, D. C. (1994). Applied and Environmental Microbiology, 60, 3292-3299.

21. Kostinek, M., Specht, I., Edward, V. A., Schillinger, U., Hertel, C., Holzapfel, W. H., et al. (2005). Systematic and Applied Microbiology, 28, 527-540.

22. Ndoye, B., Lebecque, S., Dubois-Dauphin, R., Tounkara, L., Guiro, A. T., Kere, C., et al. (2006). Enzyme and Microbial Technology, 39, 916-923.

23. Béal, C., \& Corrieu, G. (1994). Lebensmittel-Wissenschaft and Technologie, 27, 86-92.

24. Ishibashi, N., Tatematsu, I., Shimamura, S., Tomita, M., \& Okonogi, S. (1985). Drugs and foodstuffs (pp. 227-232). Paris: International Institute of Refrigeration.

25. Chatterjee, M. T., Seunath, A., Khalawan, S. A., \& Curran, B. P. G. (2000). Microbiology, 146, 877-884.

26. Castro, H. P., Teixeira, P. M., \& Kirby, R. (1977). Journal of Applied Microbiology, 82, 87-94.

27. Ndoye, B., Weekers, F., Diawara, B., Guiro, A. T., \& Thonart, P. (2007). Journal of Food Engineering, 79, 1374-1382.

28. Sow, N. M., Dubois-Dauphin, R., Roblain, D., Guiro, A. T., \& Thonart, P. (2005). Australian Journal of Biotechnology, 4, 409-421.

29. Howe, A. G., \& Schilmiller, A. L. (2002). Current Opinion in Plant Biology, 5, 230-236.

30. Halliwell, B., \& Chirico, S. (1993). American Journal of Clinical Nutrition, 57, 715-725.

31. Zhang, W., Shi, B., \& Shi, J. (2007). Journal of the American Leather Chemists Association, 102, 99105.

32. França, M. B., Panek, A. D., \& Eleutherio, E. C. A. (2007). Molecular \& Integrative Physiology, 146, 621-632.

33. Nawar. (1996). Food. chem. F. O. R. New York, Marcel Dekker, Inc 1, pp 225-319. 